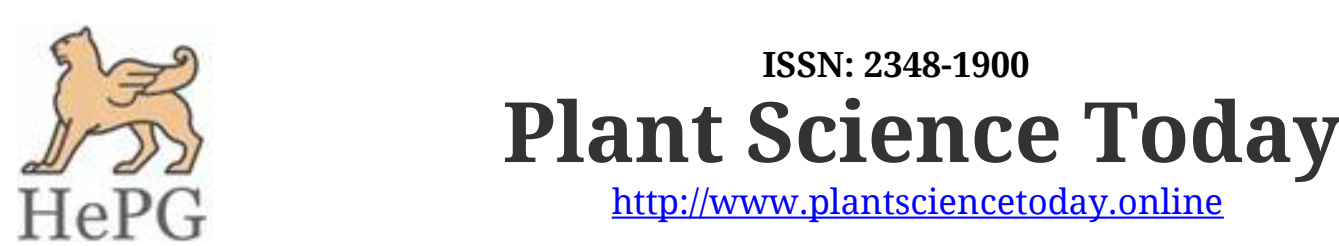

open $\odot$ access

Research Article

\title{
Diversity of microphytes from some reservoirs of Kolhapur district
}

\author{
Aparna Patil ${ }^{1}$, Sachin Patil ${ }^{2 *} \&$ Sanjay Sathe ${ }^{3}$ \\ ${ }^{1}$ Department of Botany, Bhogawati Mahavidyalaya, Kurukali 416 001, India \\ ${ }^{2}$ Department of Botany, Faculty of Science, The M. S. U. of Baroda, Vadodara 390 002, India \\ ${ }^{3}$ Department of Botany, S. S. Dr. Bapuji Salukhe Mahavidyalay, Miraj 416 410, India
}

\section{Article history}

Received: 23 July 2019

Accepted: 19 August 2019

Published: 06 October 2019

\section{Publisher}

Horizon e-Publishing Group

\author{
*Correspondence \\ Sachin Patil \\ 凶sach2010d@gmail.com
}

\begin{abstract}
Aquatic microphytes are pioneer organisms of an aquatic food chain. The productivity of an aquatic environment depends on the density of microphytes. These produce the food material on which other organisms in the ecosystem sustain. In this context, the present investigation was undertaken to study the diversity of microphytes from some reservoirs (Belawale Budruk, Benikare, Karanjivane, Sonali and Murgud) of Kolhapur District, Maharashtra. About 108 species of microphytes were identified from these lakes. Maximum diversity is observed from Chlorophyceae, followed by Bacillariophyceae and Cyanophyceae.
\end{abstract}

Keywords: Limnobotany; diversity; phytoplankton; Chlorophyceae

Citation: Patil A, Patil S, Sathe S. Diversity of microphytes from some reservoirs of Kolhapur district. Plant Science Today 2019;6(4):495-504. https://doi.org/10.14719/pst.2019.6.4.617

Copyright: ( ) Patil et al (2019). This is an open-access article distributed under the terms of the Creative Commons Attribution License, which permits unrestricted use, distribution, and reproduction in any medium, provided the original author and source are credited (https://creativecommons.org/licenses/by/4.0/).

Indexing: Plant Science Today is covered by Scopus,Web of Science, BIOSIS Previews, ESCI, CAS, AGRIS, CABI, Google Scholar, etc. Full list at http://www.plantsciencetoday.online

\section{Introduction}

Microphytes are the small, tiny unicellular or multicellular planktonic alga observed in all aquatic ecosystems (fresh, estuarine and marine). They are grouped into filamentous algae and planktonic algae. The filamentous algae are uniseriate, forming long chain, thread or filament. These chains, threads and filaments are intertwined to form a mat which resembles with wet wool (1). They are commonly known as pond scum or algal blooms. However, planktonic algae or phytoplankton are microscopic, free floating plants unicellular or multicellular algae exist individually or in colony or in chain or groups (2). On the basis of species, their size can be ranging from a few micrometers $(\mu \mathrm{m})$ to a hundred micrometers. They are commonly known as "green water algae or pea soap algae". The phytoplankton are not having root, stem and leaves, but they are capable to perform the photosynthesis and produce approximately half of the atmospheric oxygen by using the carbon dioxide to grow photo autotrophically (3).

Most of the microphytes are small and numerous in natural waters, usually at the level of $10^{2}$ to $10^{6}$ cells $/ \mathrm{ml}$. This makes their study very convenient even with small volume of water. It is a convenient tool in ecological studies, which help to be valid, the biotic components of reservoirs as a 


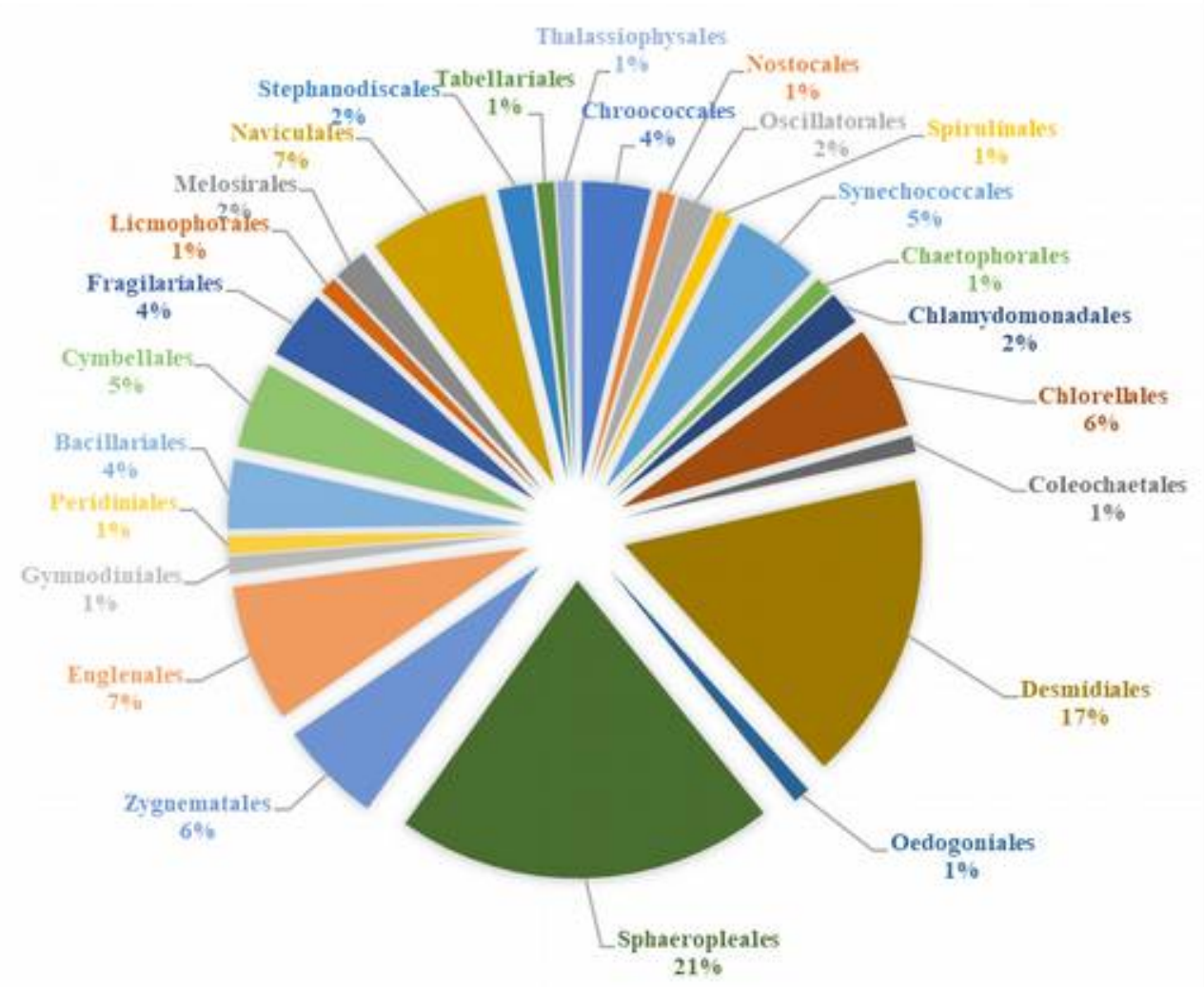

Fig. 1. Pie-Chart showing most specious order of microphytes in studied reservoirs of Kolhapur district



Fig. 2. Pie-Chart showing most specious family of microphytes in studied reservoirs of Kolhapur district

part of water pollution, investigations as well as in biological waste water treatment plants (4).

Now a days the quality of water bodies gets polluted due to an increase in human activities. Thus, it underlines to study the seasonal limnobotany with reference to microphytes diversity. The microphytes in water may exist in the forms like filamentous and planktonic forms. The limnobotanical study with special reference to algal diversity plays an important role to understand the status of water 


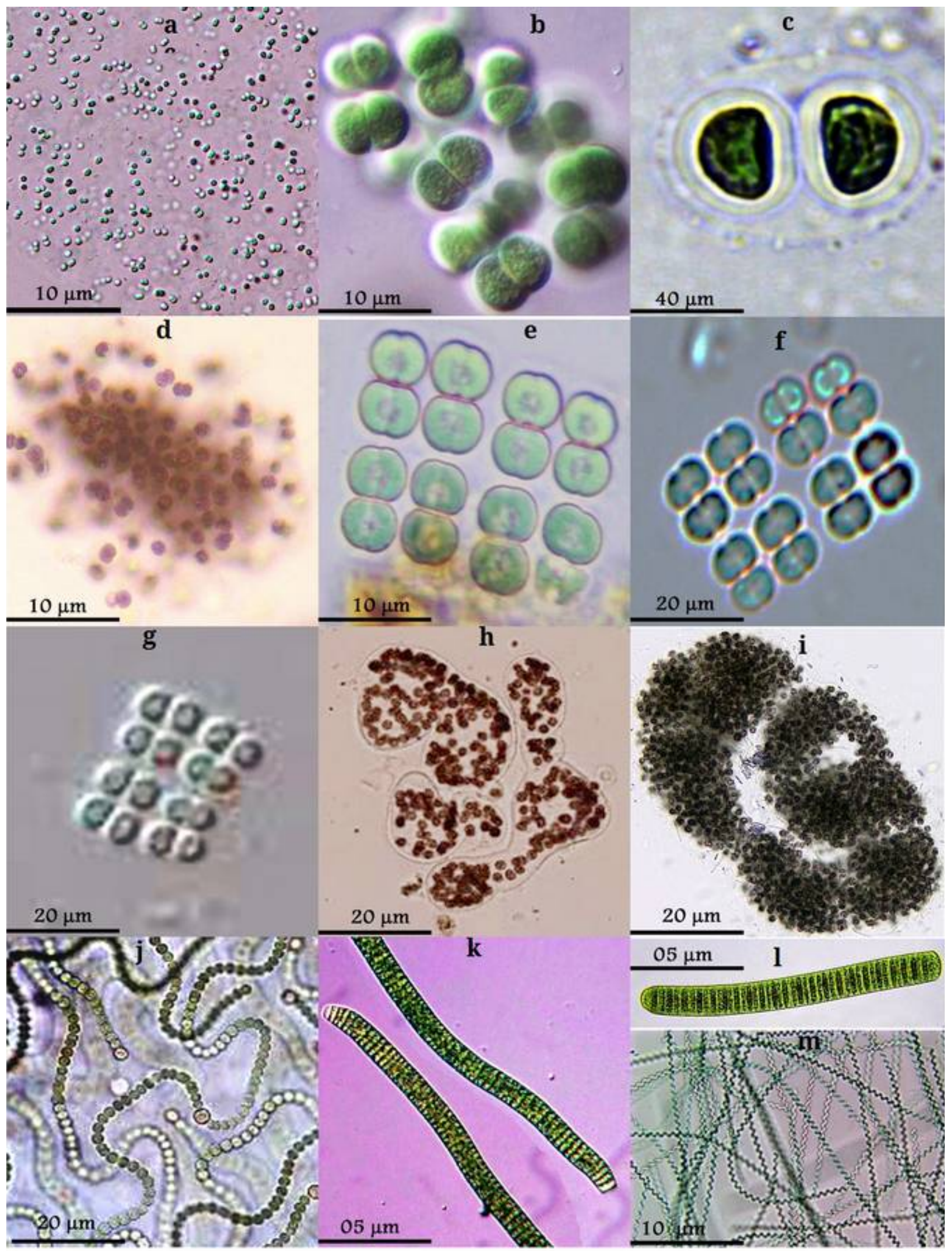

Fig. 3. a. Aphanocapsa grevillea, b.Chroococcus limneticus, c. Chroococcus turgidus d. Coelosphaerium kuetzingianum, e. Merismopedia elegans f. Merismopedia glauca g. Merismopedia punctata, h. Microcystis aeruginosa, i. Microcystis incerta, j. Nostoc paludosum, k. Oscillatoria subbrevis, l. Oscillatoria tenuis, m. Spirullina nordstedtii

bodies. The analysis of water samples to study the microphytes from reservoirs of Kolhapur district will help to conceptualize the extent of requirement and also help to know their status. To establish status report, limnobotanical investigation in terms of algal diversity has got prime importance. During present investigation diversity of microphytes in some reservoirs from Kolhapur district were studied. 


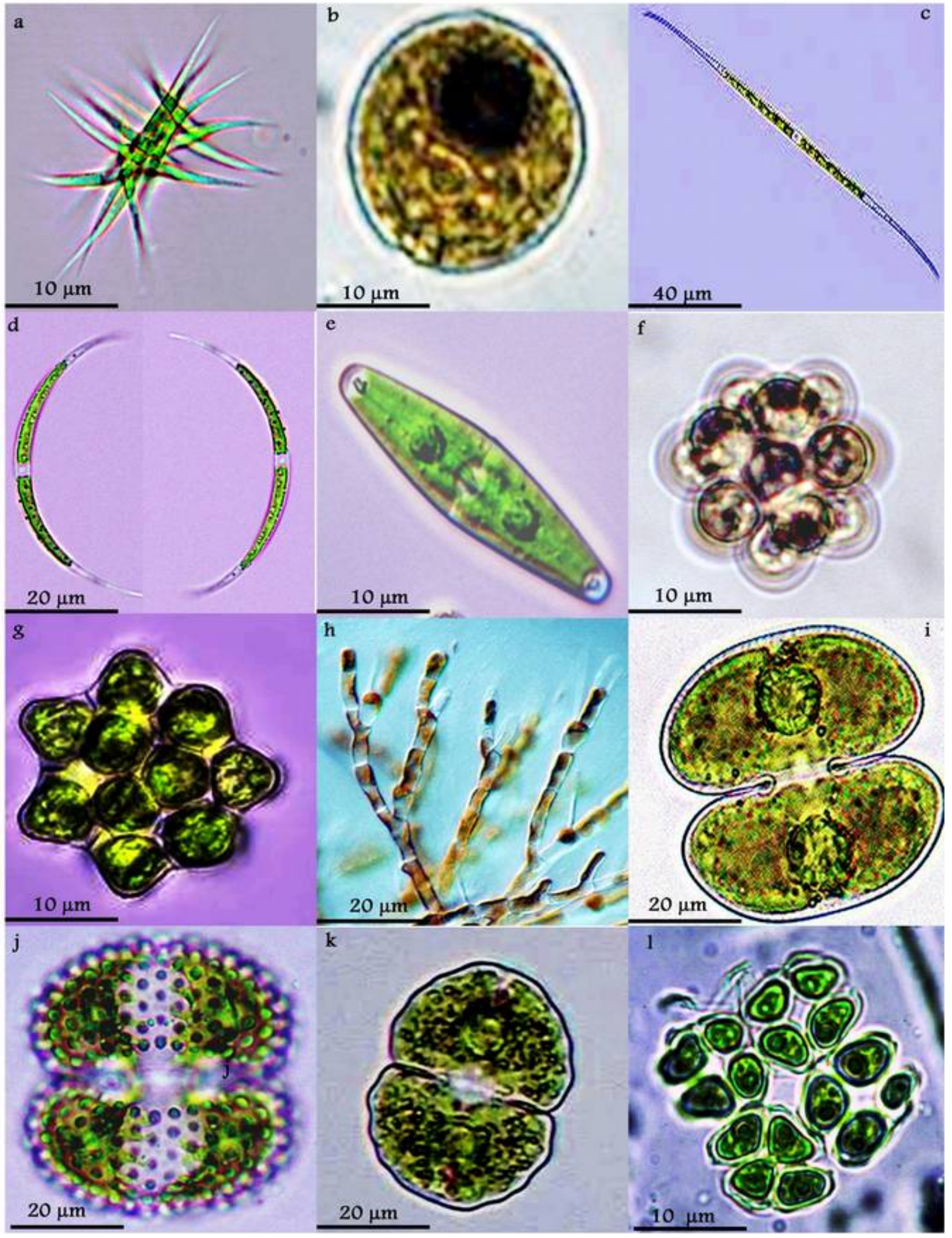

Fig. 4. a. Ankistrodesmus fusiformis b. Chlamydomonas elegans c. Closterium aciculare d. Closterium acutum e. Closterium navicula f. Coelastrum microporum g. Coelastrum sphaericum, h. Coleochaete orbicularis, i. Cosmarium depressum, j. Cosmarium reniforme, k. Cosmarium undulatum, l. Crucigenia truncata

\section{Materials and Methods}

The diversity of Microphytes from some reservoirs of Kolhapur district is studied (Satellite Map 1-5, images were taken from google earth). For the study of microphytes 100 litters of water were filtered through the nylon mesh $(05-200 \mu \mathrm{m})$. Filtrate was collected in $100 \mathrm{ml}$ prelabelled plastic bottles and fixed in $0.4 \%$ 


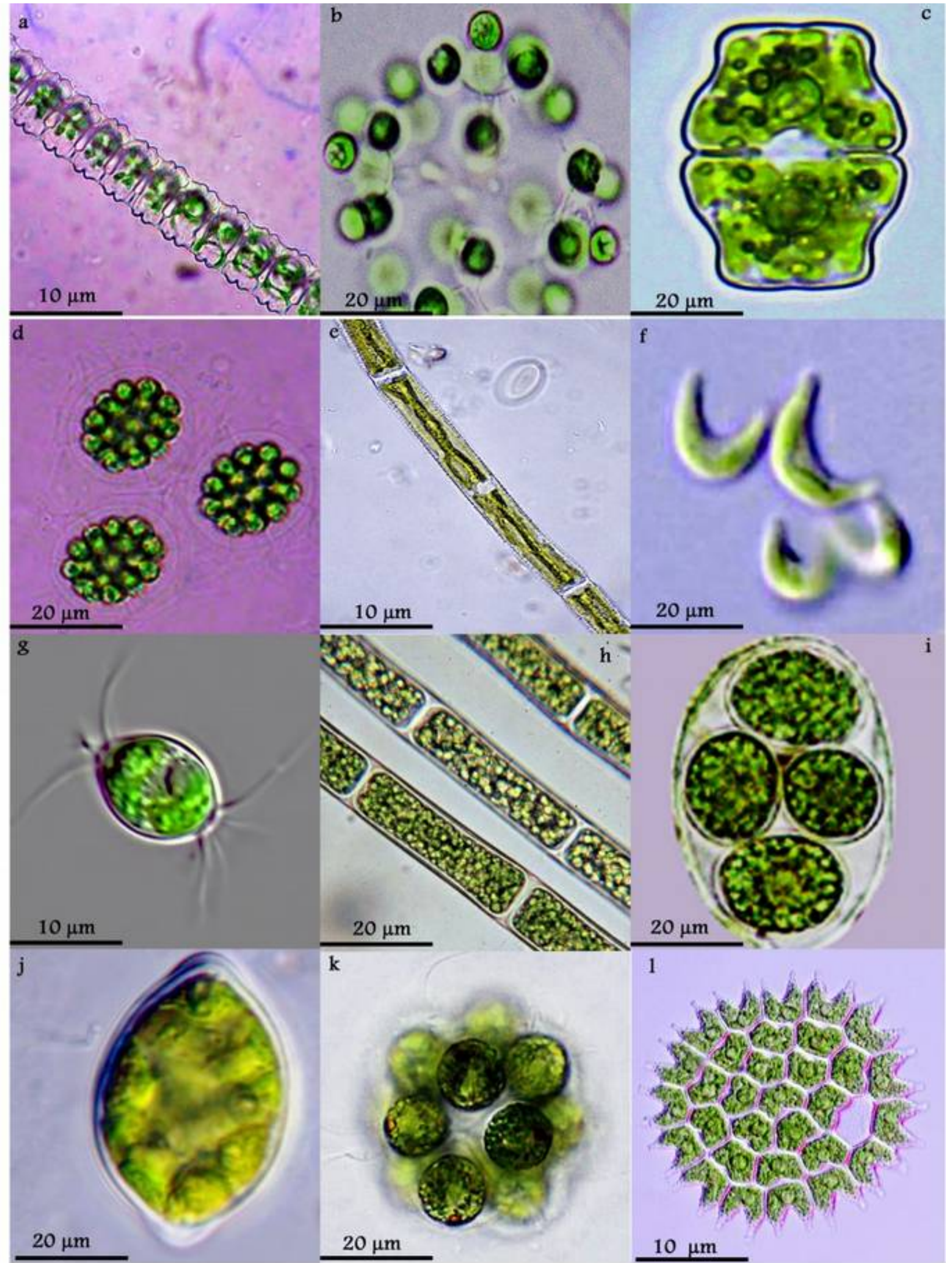

Fig. 5. a. Desmidium swartzii, b. Dictyosphaerium pulchellum, c. Eustrum insulare,d. Eudorina elegans, e. Genicularia elegans, f. Kirchneriella lunaris, g. Lagerheimia quadriseta, h. Mougeotia scalaris, i. Oocystis gigas, j. Oocystis gloeocystiformis, k. Pandorina morum, l. Pediastrum duplex var. clathratum

formalin. Preserved samples were studied after the proper settlement of the algal debris. The samples were examined under the microscope (LICA 2000) at $10 \mathrm{x}, 40 \mathrm{x}$ and $100 \mathrm{x}$ depending upon the structure and size of the algal cells. The identification of various types of phytoplankton were done with help of different flora (5-13). 


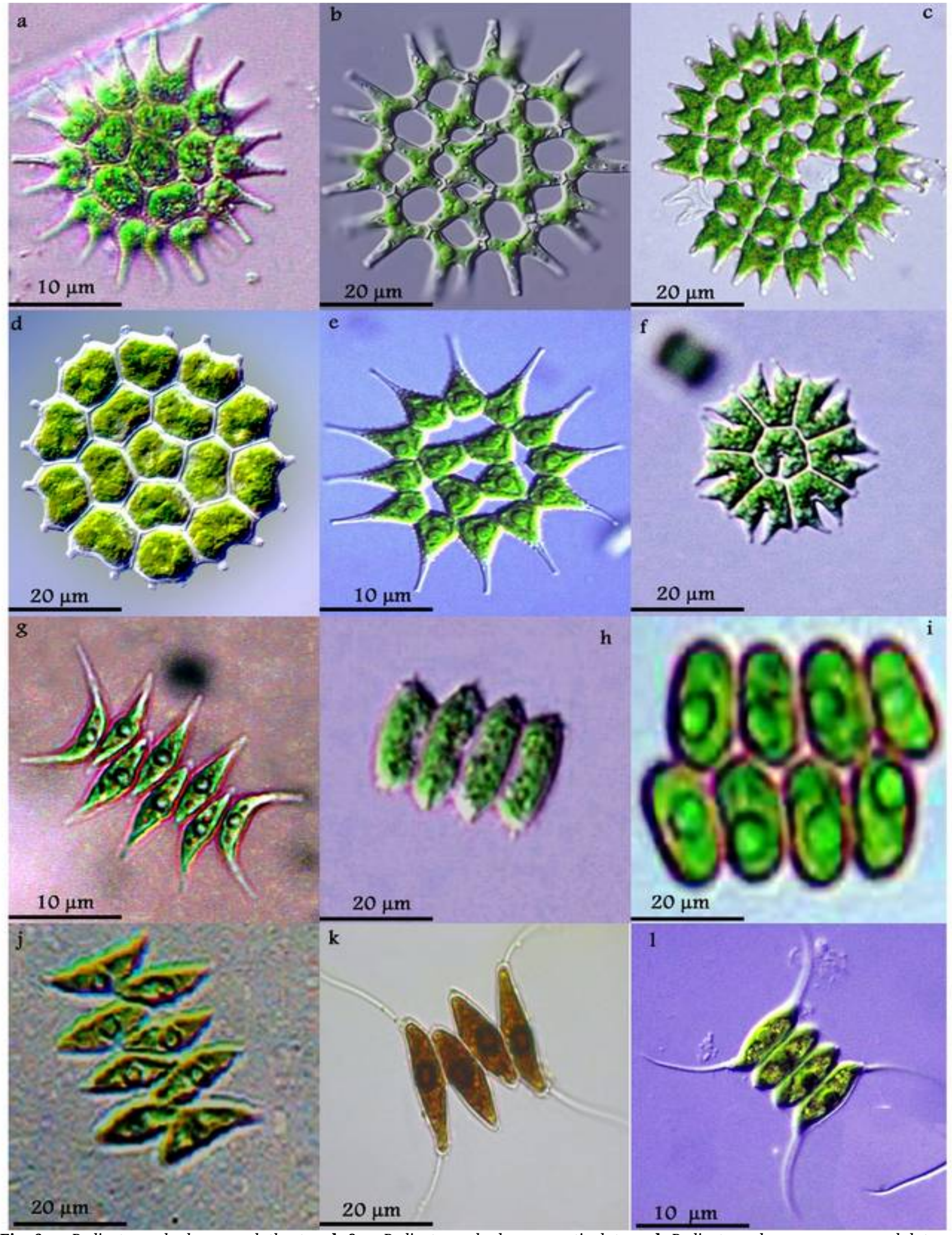

Fig. 6. a. Pediastrum duplex var. clathratum b \& c. Pediastrum duplex var. reticulatum, d. Pediastrum boryanum var. undulatum e. Pediastrum simplex, f. Pediastrum tetras, g. Scenedesmus acuminatus, h. Scenedesmus bijugatus, i. Scenedesmus bijugatus var. irregularis, j. Scenedesmus dimorphus, k. Scenedesmus hytrix, l. Scenedesmus quadricauda

\section{Results}

The concepts of periodicity, succession and response to environmental changes on diversity of phytoplankton attract the interest of many ecologists.
$(14,15)$. Moreover, number and species of phytoplankton serves to determine the quality of water body. It was then the subsequent works were aimed at finding out the causative factors responsible for the growth and sustenance of groups of 


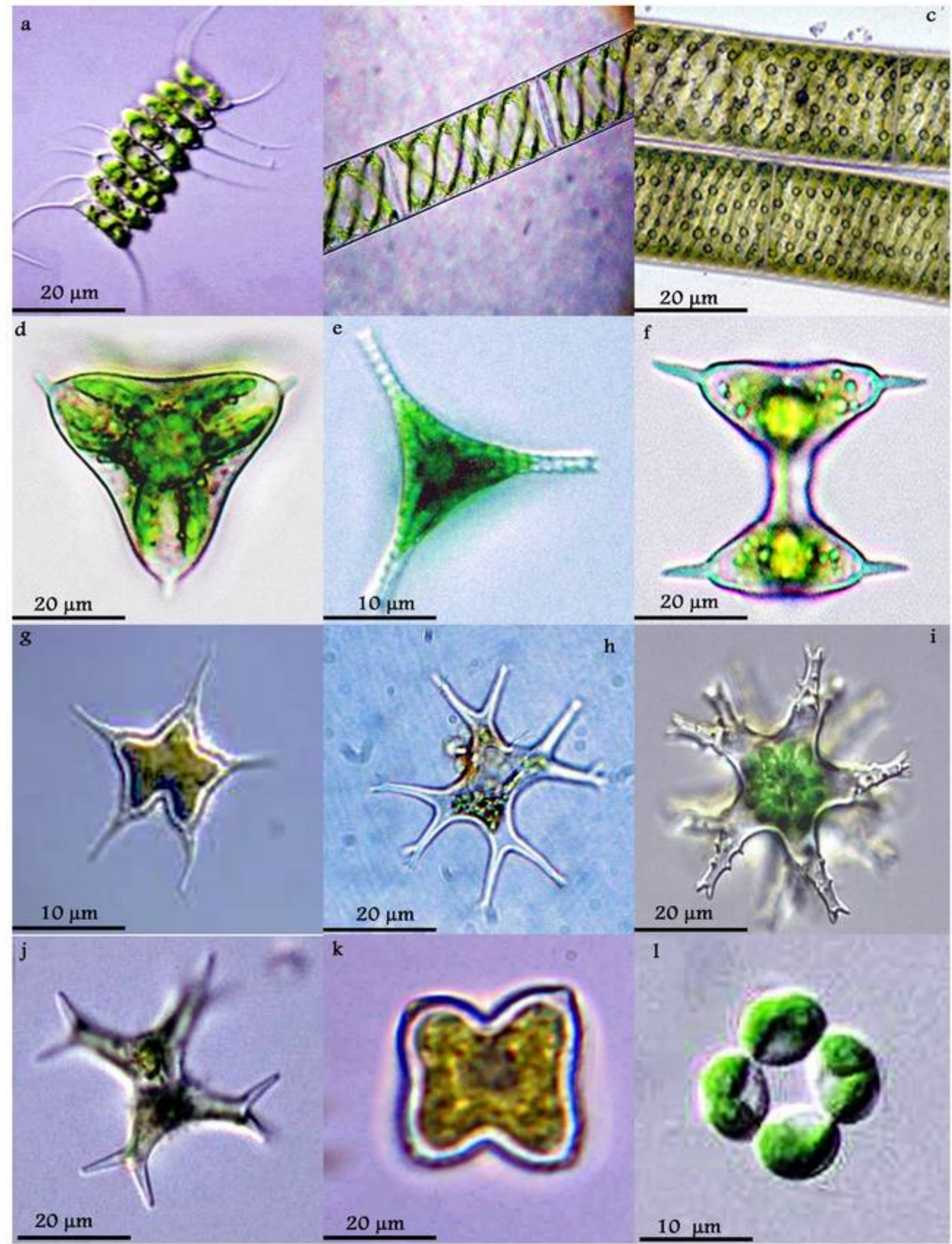

Fig. 7. a. Scenedesmus quadricauda var. minutum, b. Spirogira condensata, c. Spirogyra crassa, d. Staurastrum dickie, e. Staurastrum dijuctum, f. Staurastrum glabrum var. depressum, g. Tetraedron caudatum, h. Tetraedron gracile, i. Tetraedron incus, $\mathbf{j}$. Tetraedron limneticum, $\mathbf{k}$. Tetraedron minimum, l. Tetrastrum triangulare

phytoplankton or zooplankton (16). During the present investigation microphytes diversity was studied from reservoirs of Kolhapur district (Table 1 and Fig. 1-9). About 108 species belonging 36 families, 25 orders spread over 5 major class of algae were identified from studied reservoirs (Table 1). 


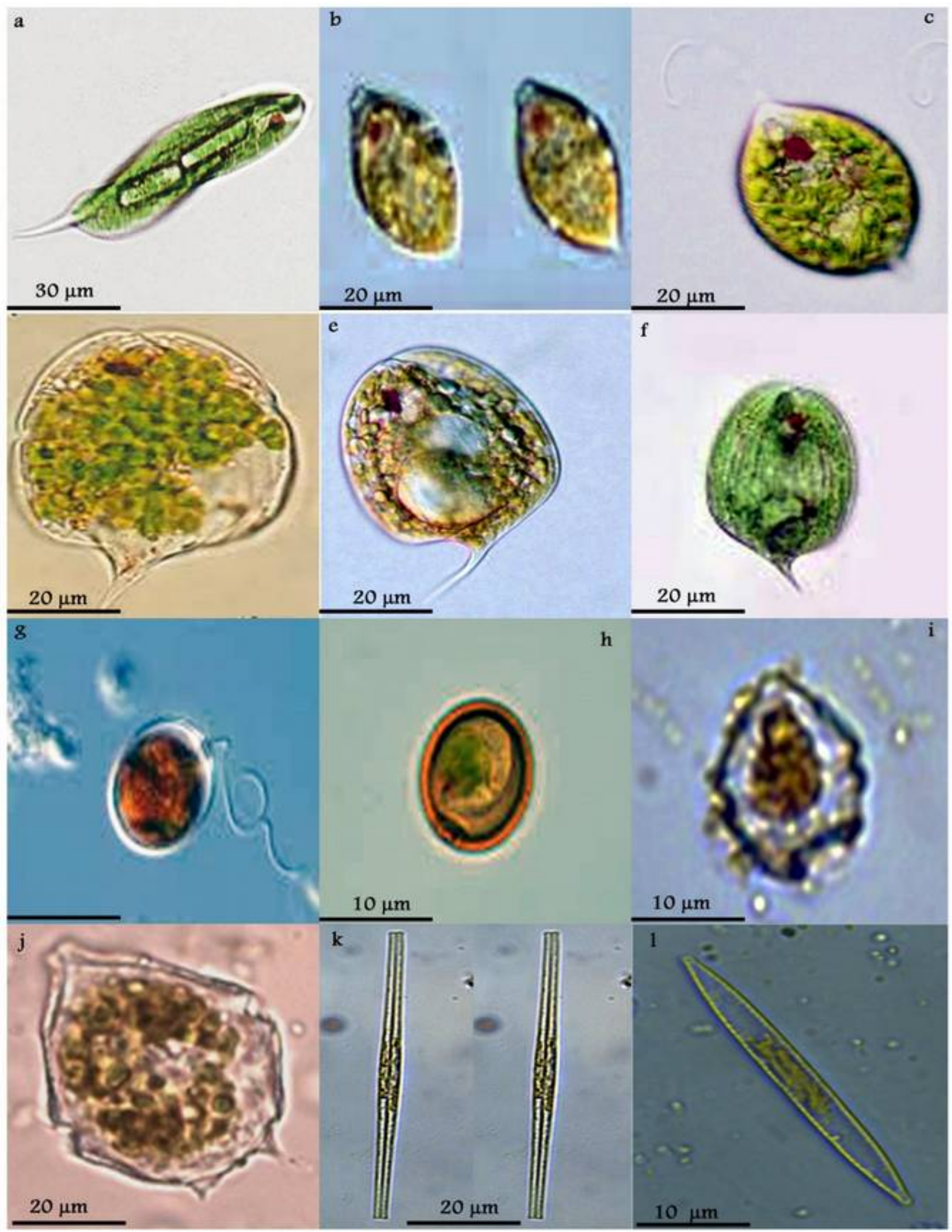

Fig. 8. a. Euglena acus, b. Lepocinclis acuta, c. Lepocinclis fusiformis, d. Phacus acuminatus, e. Phacus anacoelus, f. Phacus curvicauda, g. Trachelomonas hispida, h. Trachelomonas volvocina, i. Gymnodinium palustrae, j. Peridinum aciculiferum, k. Nitzschia acicularis, 1., Nitzschia archibaldii

The most specious families are Closteriaceae, Selanatraceae, Hydrodictyaceae followed by Scenedesmaceae, Euglenaceae, Volvocaceae and Coleochaetaceae (Fig. 2).

\section{Discussion}

Study on the diversity of phytoplankton from in and around the wetlands of Kolhapur and reported 174 species of phytoplankton, of which 24 


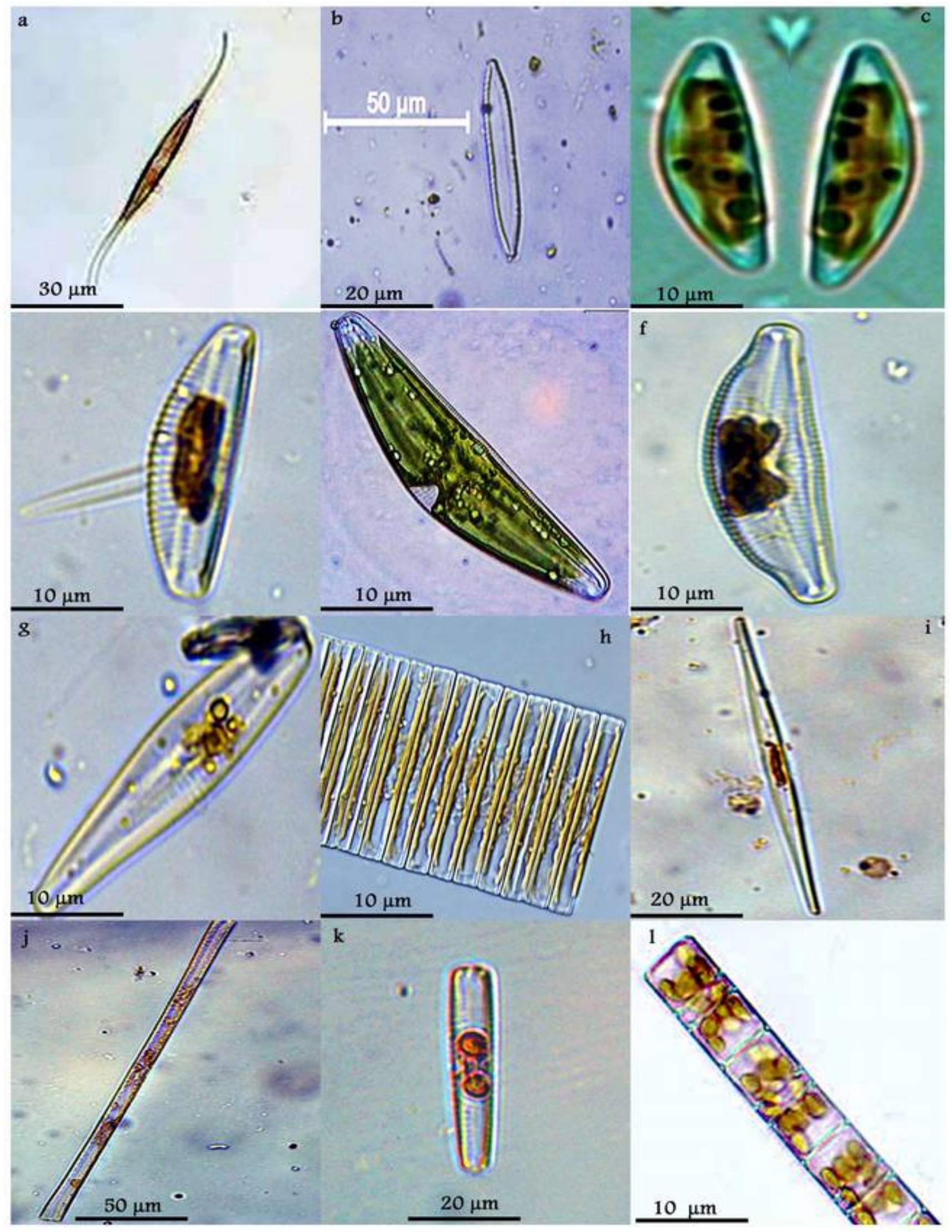

Fig. 9. a. Nitzschia Closterium, b. Nitzschia palea, c. Cymbella affinis, d. Cymbella helvetica, e. Cymbella lanceolata, f. Cymbella tumida, g. Gomphonema subventricosum, h. Frustulia saxonica, i. Synedra acus, j. Synedra ulna, k. Licmophora abbreviata, 1. Melosira granulata

species are filamentous forms and 150 species are of colonial or unicellular forms (10). Another study on the phytoplankton diversity of lakes in Shivaji University, Kolhapur and reported 78 species of phytoplankton belonging to 5 major classes viz., Cyanophyceae, Chlorophyceae, Euglenophyceae, Dinophyceae and Bacillariophyceae (17). Reports are there on the impact of anthropogenic activities 
on the phytoplankton diversity of Rajaram reservoir, Kolhapur (Maharashtra) (18) that recorded 120 species of phytoplankton belonging to 5 major classes of phytoplankton.

Similar results were recorded during the present investigation and the authors identified 108 species of phytoplankton belonging to 5 major classes viz., Cyanophyceae, Chlorophyceae, Euglenophyceae, Dinophyceae and Bacillariophyceae. Amongst these Chlorophyceae (57) and Bacillariophyceae (26) shows maximum diversity followed by Cyanophyceae (13), Euglenophyceae (08) and Dinophyceae (02). Most specious genera are Pediastrum (06), Scenedesmus (06), Staurastrum (06), Tetraedron (06) followed by the genera viz., Cosmarium (04), Cymbella (04), Nitzschia (04), Navicula (04) and Spirogyra (04). Authors also stated that the many Cyanophyceae, Chlorophyceae and Bacillariophyceae members (pollution indicators) which were reported earlier from Kolhapur district are not reported from the studied reservoirs (1, 10-11, 13, 17-18). Hence, it indicates the healthy condition of reservoirs.

\section{Acknowledgements}

Authors are very much thankful to the Principal, Bhogawati Mahavidyalaya, Kurukali for providing the laboratory facilities.

\section{Competing Interests}

The authors don't have any competing interests.

\section{Authors contributions}

AP collected the water samples from the reservoirs of Kolhapur district and microphyte photographs were taken. SP identified the species and written preliminary draft of manuscript. SS confirmed the species and finalise the manuscript.

\section{References}

1. Gaikwad SG. Studies on the reservoirs of Shivaji University Campus, Kolhapur, (Maharashtra) India. A Ph.D. Thesis submitted to Shivaji University, Kolhapur. 2017.

2. Sharma OP. Algae: Series on diversity of microbes and cryptogams. 2011; pp 389.

3. Vashishta, BR, Sinha AK, Singh VP. Botany for Degree Students - Algae. 2010; pp 612.
4. Reynolds, CS. The ecology of freshwater phytoplankton. Cambridge Univ. Press, Cam- bridge and New York. 1984; p 384.

5. West W and West GS. A Monograph of the British Demidiaceae IV. Adlard and Son, London. 1912; pp 1194.

6. Fritsch FE. The Structure and reproduction of the algae. Vol. I. Vikas Publishing House, PVT. LTD. New Delhi. 1935; 767 pp.

7. Prescott, GW. Algae of the Western Great Lakes Area. Michigan: W. M. C. Brown Company Publishers.

8. Sarode, PT, Kamat, ND. Freshwater diatoms of Maharashtra. 1962; pp 1000.

9. Cox E. Identification of freshwater diatoms from live material. Chapman \& Hall, London. 1996; pp 158.

10. Bhosale LJ, Patil SM, Dhumal SN, Sabale SS. Occurrence of phytoplankton in the water bodies of Miraj Tahasil of Maharashtra. The Ecoscan, 2010; 4: 73-76.

11. Bhosale LJ, Patil SM, Dhumal SN, Sabale AB. Occurrence of phytoplankton in the lakes in and around Kolhapur city (Maharashtra). Indian Hydrobiology. 2010; 12 (2): 133-42.

12. Bhosale LJ, Sabale AB and Mulik NG. Survey and Status Report on Some Wetlands of Maharashtra, Final report of project submitted to Shivaji University, Kolhapur, India. 1994; pp. 60.

13. Bhosale LJ, Patil SM, Dhumal SN, Sathe SS. Phytoplankton biodiversity in water bodies of Tahasil Kavathe Mahankal (Sangli District) during post summer period. Indian Hydrobiology. 2010; 12 (2): 190-94.

14. West GS, Fritsch FE. Treatise on the British Freshwater Algae, 2nd edn. Cambridge University Press, Cambridge. 1927; pp: 534.

15. Wilson J. The "intermediate disturbance hypothesis" of species coexistence is based on path dynamics. N. Z. J. Ecol. 1994; 18: 176-81.

16. Sasikala T, Manjulatha C, Raju DVSN. Freshwater Phytoplankton Communities in Varaha Reservoir, Kalyanapulova, Visahkapatnam. Adv Crop Sci Tech. 2017; 5(2): 262.

17. Anekar S, Patil S, Dongare M. An account of Algal diversity from the lakes of Shivaji University campus Kolhapur (Maharashtra), India. Ad. Plant Sci. 2012; 25 (2): 629-32.

18. Gaikwad SG, Patil SM, Dongare MM. Impact of anthropogenic activities on the phytoplankton diversity of Rajaram reservoir, Kolhapur, Maharashtra, India. Nat. Envi. Poll. Tech. 2014; 12 (2): 261-66. 